\title{
HUBUNGAN DUKUNGAN SOSIAL KELUARGA DENGAN TINGKAT DEPRESI PADA LANSIA DI KELURAHAN SADING
}

\author{
Gusti Ayu Trisna Parasari dan Made Diah Lestari \\ Program Studi Psikologi, Fakultas Kedokteran, Universitas Udayana \\ gustiayutrisna@gmail.com
}

\begin{abstract}
Abstrak
Lansia adalah kelompok lanjut usia yang rentan mengalami depresi. Depresi lansia disebabkan oleh kurangnya kemampuan beradaptasi terhadap perubahan pada diri akibat kemunduran fisik, mental dan sosial yang dialami. Keparahan gangguan depresi lansia dikategorikan menjadi tiga tingkatan yaitu tidak depresi, depresi ringan dan depresi sedang/berat. Dukungan sosial keluarga berperan penting dalam membantu lansia dalam beradaptasi terhadap perubahan yang terjadi sehingga dapat menurunkan tingkat depresi. Penelitian kuantitatif dengan pendekatan korelasional ini bertujuan untuk mengetahui hubungan antara dukungan sosial keluarga dengan tingkat depresi pada lansia di Kelurahan Sading. Sampel terdiri dari 233 lansia di Kelurahan Sading yang diambil dengan menggunakan teknik simple random sampling. Penelitian ini menggunakan dua skala pengukuran yaitu skala dukungan sosial keluarga dan skala tingkat depresi (Geriatric Depression Scale) yang diadaptasi dari Yesavage dkk.(dalam Azizah, 2011). Skala dukungan sosial keluarga terdiri dari 33 item dengan nilai reliabilitas $=0,968$ dan skala tingkat depresi terdiri dari 30 item dengan nilai reliabilitas $=0,948$. Teknik analisis yang digunakan pada penelitian ini adalah korelasi Rank Spearman. Hasil analisis menunjukkan bahwa ada hubungan yang signifikan antara dukungan sosial keluarga dengan tingkat depresi $(p=0,000 ; p<0,05)$. Koefisien korelasi $r=-0,847$ sehingga dapat disimpulkan dukungan sosial keluarga memiliki hubungan yang berlawanan arah dengan tingkat depresi. Hal ini berarti bahwa semakin tinggi dukungan sosial keluarga yang diterima, maka tingkat depresi pada lansia di Kelurahan Sading akan lebih rendah.
\end{abstract}

Kata Kunci: Dukungan Sosial Keluarga, Tingkat Depresi dan Lansia

\begin{abstract}
Elderly are age group that susceptible to depression. Depression in elderly is caused by lack of ability to adapt to changes in self as result of physical, mental and social decline. Severity of elderly depressive disorders are categorized into three levels, namely no depression, mild depression and moderate/severe depression. Family social support plays an important role in helping the elderly in adapting to the changes that occur in order to reduce the level of depression. This quantitative research with correlation approach aims to determine the relationship between family social support with level of depression in elderly in Sading Village. The samples cosisted of 233 elderly in Sading Village were taken using simple random sampling technique. This study uses two scales of measurement namely the family social support scale and the level of depression scale (Geriatric Depression Scale) adapted from Yesavage et al. (in Azizah, 2011). Family social support scale consists of 33 items with the reliability value $=0,968$ and level of depression scale consists of 30 items with the reliability value $=0,948$. The analysis technique used in this study is the Spearman Rank correlation. The analysis result showed that there was a significant relationship between family social support with level of depression $(p=0,000, p<0,05)$. The correlation $r=-0.847$ can be concluded that family social support has a opposite direction relationship with level of depression. This means that the higher family social support received, then the level of depression in elderly in Sading Village would be lower.
\end{abstract}

Keywords: Family Social Support, Level coefficient of Depression and Elderly 


\section{LATAR BELAKANG}

Dewasa ini, usia harapan hidup penduduk Indonesia telah memasuki angka 72 tahun, hal ini mengakibatkan terjadinya peningkatan jumlah penduduk lanjut usia atau lansia (Kementrian Pemberdayaan Perempuan dan Perlindungan Anak Republik Indonesia, 2011). Badan Pusat Statistik tahun 2010 mencatat jumlah lansia di Indonesia telah mencapai angka 18.043.712 jiwa. Pertumbuhan jumlah lansia dari tahun ke tahun diprediksi akan mengalami peningkatan tajam. Pada tahun 2025, diprediksi jumlah lansia membengkak menjadi 40 jutaan jiwa, bahkan di tahun 2050 jumlah lansia diperkirakan akan menjadi 71,6 juta jiwa (Utari, 2012). Peningkatan jumlah lansia yang tidak dibarengi dengan peningkatan upaya pemberian jaminan dan dukungan sosial yang memadai, akan berdampak pada semakin meningkatnya angka ketergantungan penduduk usia tua terhadap penduduk usia produktif (old dependency ratio), dengan kata lain beban yang harus ditanggung oleh penduduk usia produktif pun akan semakin meningkat.

Menurut data Badan Pusat Statistik tahun 2010, jumlah penduduk Indonesia yaitu sebesar 237.641.326 jiwa, meliputi penduduk lansia (60 tahun keatas) yang mencapai angka 18.043.712 jiwa, sementara itu jumlah penduduk usia produktif (15-59 tahun) yang mencapai 156.994.351 jiwa, dengan demikian rasio ketergantungan penduduk lansia (old dependency ratio) berada pada angka 11,5 , yang artinya setiap 100 orang usia produktif terdapat sekitar 11 orang lansia. Angka ini mencerminkan besarnya beban ekonomi yang harus ditanggung penduduk produktif untuk membiayai penduduk lansia, padahal dalam GBHN 1993 disebutkan bahwa bagi lansia perlu diberi kesempatan untuk berperan dalam pembangunan karena mereka memiliki pengalaman, keahlian dan kearifan sehingga diharapkan agar selalu sehat dan produktif, sehingga dapat menjadi lansia yang berhasil atau disebut successful aging (Suardiman, 2011).

Konsep successful aging mengacu pada ketahanan orang-orang yang berhasil mencapai keseimbangan positif antara keuntungan dan kerugian selama proses penuaan (Ouwehand, de Rider \& Benzing, 2006). Sejalan dengan konsep successful aging, maka dapat dikatakan bahwa lansia tidak hanya menghadapi penurunan namun mereka dapat terus aktif mengembangkan diri dalam berbagai bidang, sehingga dalam hal ini kesehatan merupakan aspek yang sangat penting. Undang-undang No.36 Tahun 2009 Tentang Kesehatan pasal 1 menyatakan bahwa kesehatan adalah keadaan sejahtera dari badan, jiwa, dan sosial yang memungkinkan setiap orang hidup produktif secara sosial dan ekonomis (Kementrian Kesehatan Republik Indonesia, 2009). Berdasarkan pengertian kesehatan, maka dapat dikatakan bahwa sehat tidak hanya terbebas dari masalah fisik namun juga terbebas dari masalah psikososial salah satunya depresi.
Menurut Undang-undang Republik Indonesia no 13 tahun 1998 tentang kesejahteraan lanjut usia pada bab I pasal 1 ayat 2, yang dimaksud dengan lansia adalah seseorang yang telah mencapai usia 60 tahun ke atas. Di masa tua seseorang akan mengalami kemunduran fisik, mental dan sosial secara bertahap (Azizah, 2011). Terjadinya kemunduran tersebut dapat berakibat pada terjadinya permasalahan di masa tua antara lain masalah ekonomi, masalah sosial, masalah kesehatan dan masalah psikologis.

Masalah ekonomi pada lansia terjadi ketika memasuki masa pensiun atau berhentinya pekerjaan utama akibat adanya penurunan produktivitas kerja, sehingga terjadi penurunan pendapatan yang terkait dengan pemenuhan kebutuhan sehari-hari. Masalah sosial yaitu terjadi karena adanya perubahan nilai sosial masyarakat yang mengarah pada tatanan masyarakat individualistik, berpengaruh pada lansia yang menjadi kurang mendapat perhatian, sehingga tersisih dari kehidupan masyarakat dan terlantar. Masalah kesehatan di masa tua berhubungan dengan adanya penurunan fungsi fisik sehingga rentan terhadap penyakit, sehingga diperlukan pemberian layanan kesehatan dari orang-orang disekelilingnya. Terakhir yaitu masalah psikologis yang dapat berupa kesepian, terasing dari lingkungan, ketidakberdayaan, perasaan tidak berguna, kurang percaya diri, ketergantungan, ketelantaran terutama untuk lansia yang miskin, post power syndrome dan sebagainya (Suardiman, 2011). Bukanlah hal yang mudah bagi lansia untuk mengatasi masalah tersebut seorang diri mengingat kondisi tubuhnya mengalami penurunan, namun di sisi lain, jika tidak diatasi dengan baik, maka masalah-masalah tersebut nantinya dapat menciptakan kondisi stres yang dirasakan ketika menjalani masa tuanya. Sejalan dengan apa yang dikatakan oleh Azizah (2011) bahwa akibat dari kemunduran fungsi fisik, kognitif dan psikososial umumnya menjadi suatu stresor bagi lansia karena pada saat menjadi tua akan terjadi penurunan kemampuan beradaptasi terhadap perubahan. Kurangnya kemampuan dalam beradaptasi secara psikologis terhadap perubahan yang terjadi pada dirinya, mengakibatkan seringkali terjadi permasalahan psikososial pada lansia, salah satunya depresi.

Depresi adalah kondisi emosional yang umumnya ditandai dengan kesedihan yang amat sangat, perasaan tidak berarti dan merasa bersalah, menarik diri dari orang lain, terganggunya pola tidur, kehilangan selera makan, hasrat seksual, serta minat dan kesenangan dalam aktivitas yang biasa dilakukan (Davison, Neale \& Kring, 2010). Depresi merupakan salah satu penyakit yang banyak terjadi di kalangan lansia. Pada tahun 2008 prevalensi depresi pada lansia di dunia berkisar $8-15 \%$ dan hasil meta analisis dari laporan negara-negara di dunia mendapatkan prevalensi ratarata depresi pada lansia adalah $13,5 \%$ (Evy, 2008). Prevalensi lansia depresi pada tahun 2020 diprediksi akan terus mengalami peningkatan terutama di negara-negara 
berkembang yaitu sebesar 15,9\% (Marchira, Wirasto \& W., 2007).

Lingkungan tempat tinggal yang bervariasi merupakan salah satu karakteristik lansia di Indonesia, yaitu terbagai atas lansia yang tinggal di panti wredha atau tinggal di komunitas. Berdasarkan studi komparasi oleh Wulandari (2011) terhadap lansia di Semarang, menemukan bahwa proporsi depresi pada lansia di komunitas $60 \%$ lebih besar daripada proporsi depresi pada lansia di panti wreda yaitu sebesar 38,5\%. Lebih lanjut dijelaskan, besarnya angka depresi lansia di komunitas dikarenakan dukungan sosial yang kurang maupun isolasi sosial yang merupakan faktor risiko depresi.

Sading merupakan suatu kelurahan yang berada di kecamatan Mengwi, Kabupaten Badung, yaitu merupakan hasil pemekaran dari wilayah Kelurahan Sempidi pada tahun 2008. Kelurahan Sading merupakan wilayah dengan pertumbuhan penduduk yang cukup pesat, terutama jumlah penduduk lansia dari tahun ke tahun. Pada tahun 2008 jumlah lansia di Kelurahan Sading tercatat sebanyak 403 orang, sedangkan pada tahun 2009 berjumlah 488 orang. Pada akhir Nopember 2010, terdata lansia berjumlah 528 orang. Data rekapan terakhir yaitu di tahun 2013, jumlah lansia berusia 60 tahun ke atas telah mencapai angka 700 orang. Berdasarkan persentase rasio jumlah lansia dengan jumlah penduduk penduduk sebanyak 7034 jiwa, dapat dikatakan 9,9\% nya merupakan penduduk lansia yang berusia 60 tahun ke atas, oleh karena itu demi menunjang kesejahteraan lansia, peninjauan kesehatan lansia sangatlah diperlukan di Kelurahan Sading. Jika melihat besarnya jumlah kepala keluarga (KK) di kelurahan Sading yaitu $1571 \mathrm{KK}$, maka didapatkan angka rasio antara jumlah KK dengan jumlah lansia yaitu 2 : 1, yang berarti sekitar 2 keluarga setidaknya dapat menaungi 1 lansia, sehingga keluarga merupakan faktor yang dapat diandalkan keberadaannya untuk turut berperan serta dalam pemberian dukungan kepada lansia demi menunjang kesejahteraannya.

Hasil wawancara dengan perawat Puskesmas Mengwi III yang menaungi lansia di kelurahan Sading pada tanggal 17 oktober 2013 didapatkan data bahwa pemberian pelayanan terhadap lansia dilakukan berdasarkan pelaporan mengenai keluhan fisik yang dirasakan dari lansia itu sendiri, disamping itu pendataan lapangan terhadap depresi pada lansia juga belum pernah dilakukan. Adapun beberapa dari lansia dikatakan pernah mengeluhkan keluhan fisik berupa keluhan pengurangan waktu tidur hingga 2 jam sehari dan cepat merasa lelah, namun karena alasan di hari sebelumnya mereka bekerja, maka hal tersebut seringkali dianggap wajar oleh lansia itu sendiri, sehingga tidak dilakukan pemeriksaan lebih lanjut ataupun berupa rujukan ke rumah sakit. Berdasarkan kenyataan tersebut maka belum ada data mengenai berapa jumlah depresi pada lansia di kelurahan Sading, sehingga pelayanan masih terbatas pada keluhan fisik. Sejalan dengan pernyataan yang menyebutkan bahwa depresi pada lansia tersamarkan oleh gangguan fisik, selain itu terjadinya penyangkalan dan pengabaian yang dilakukan lansia terhadap proses penuaan yang dianggap normal menyebabkan tidak terdeteksinya gangguan depresi (Stanley \& Beare, 2007). Padahal keluhan-keluhan seperti gangguan tidur dan kelelahan fisik merupakan indikasi terjadinya depresi pada lansia. Hal ini juga diungkapkan pada pernyataan bahwa lansia yang depresi umumnya menunjukkan keluhan fisik daripada keluhan emosi, sehingga gejala depresi menjadi sulit dideteksi, hal tersebut mengakibatkan keterlambatan dalam penanganan (Suardiman, 2011).

Berdasarkan wawancara yang dilakukan peneliti terhadap 3 orang lansia berusia diatas 60 tahun yang tinggal di Kelurahan Sading mengenai gejala depresi yang dirasakan selama 2 minggu terakhir berdasarkan kriteria depresi menurut Davison, Neale \& Kring (2010), didapatkan hasil bahwa 2 dari 3 subjek merasakan adanya gejala depresi berupa kehilangan minat dan kegembiraan, berkurangnya konsentrasi, mudah lelah saat beraktivitas, perasaan kurang percaya diri, serta mengalami sedikit kesulitan dalam kegiatan sosial yang biasa dilakukan, bahkan seorang diantaranya mengungkapkan perasaan pesimistis terhadap kehidupannya saat ini dan memiliki gagasan rasa bersalah ketika dirinya sakit karena hanya bisa merepotkan orang lain. Berdasarkan gejala-gejala yang dirasakan lansia tersebut maka dapat disimpulkan sebanyak 2 orang lansia merasakan adanya gejala depresi, sementara 1 orang lansia tidak merasakan gejala depresi. Informasi lain yang diperoleh yaitu ketiga lansia mengutarakan bahwa memasuki usia lansia mereka merasakan adanya berbagai keluhan fisik yang timbul seperti mudah lelah, pola tidur yang berkurang (1- 4 jam sehari), varises, reumatik, insomnia, dan diabetes.

Melalui sesi wawancara mengenai dukungan yang diberikan oleh keluarga, diperoleh informasi yaitu lansia yang merasakan adanya gejala depresi mengatakan bahwa saat ini hanya tinggal bersama pasangan, karena anggota keluarganya telah berumah tangga dan memiliki kesibukan masing-masing sehingga hampir tidak pernah berkumpul bersama. Begitu pula dengan aktivitas sosial seperti mengikuti kegiatan posyandu dan senam lansia yang tidak pernah diikuti oleh lansia karena alasan tidak ada yang mengantarkan. Permasalahan ekonomi yang dialami membuat lansia bekerja seorang diri agar dapat memenuhi kebutuhan sehari-hari. Saat sakit, lansia hanya mengandalkan obat seadanya tanpa memeriksakan kondisi kesehatannya lebih lanjut dengan alasan tidak ada yang mengantarkan ke Puskesmas. Pada lansia lain yang juga merasakan adanya gejala depresi, mengungkapkan bahwa saat ini masih tinggal bersama keluarga namun kesibukan keluarga mengakibatkan lansia hanya dapat berkumpul bersama keluarga di akhir pekan, namun ketika lansia sakit, keluarga masih menyempatkan waktu untuk mengantarkan berobat ke 
rumah sakit meskipun dalam perawatan lanjutan, lansia mengandalkan tenaga pembantu rumah tangga, sementara itu saat ini lansia tidak lagi dilibatkan dalam hal pembuatan keputusan keluarga. Pada lansia yang tidak merasakan gejala depresi menyatakan bahwa saat ini hubungan dengan keluarga masih terjalin sangat erat oleh karena lansia masih tinggal bersama anggota keluarga. Saat menghadapi permasalahan seperti masalah ekonomi, anak masih memberikan uang kepadanya, sementara itu lansia juga masih dilibatkan dalam pembuatan keputusan keluarga.

Melalui pernyataan ketiga subjek lansia tersebut, dapat dilihat pada lansia dengan gejala depresi, kurang mendapatkan dukungan berupa bantuan dari keluarga dalam mengatasi permasalahan yang dihadapinya, berbeda halnya dengan lansia yang tidak mengalami gejala depresi, yang selalu mendapatkan bantuan dari keluarga ketika dihadapkan pada suatu permasalahan. Pemekaran wilayah kelurahan Sading pada tahun 2008 ditandai dengan bertambahnya jumlah KK yaitu lebih dari $700 \mathrm{KK}$. Bertambahnya jumlah KK di Kelurahan Sading merupakan indikasi bergesernya tatanan masyarakat kelurahan Sading dari keluarga luas menjadi keluarga inti. Meluasnya keluarga inti di Sading berdampak pada berkurangnya pemberian dukungan sosial oleh keluarga kepada lansia. Berdasarkan kenyataan tersebut, maka dapat disimpulkan bahwa dukungan sosial dari keluarga merupakan suatu hal yang sangat penting bagi seseorang ketika memasuki lansia dalam membantu mengatasi permasalahan yang dihadapinya.

Menurut Maryam dkk. (2008), terjadinya depresi pada lansia dipengaruhi oleh faktor resiko berupa kesehatan fisik yang buruk, perpisahan dengan pasangan, perumahan dan transportasi yang tidak memadai, kurangnya sumber finansial serta dukungan sosial yang kurang. Hubungan kejadian depresi seringkali melibatkan dukungan sosial yang tersedia yang digunakan lansia dalam menghadapi stressor (Azizah, 2011).

Dukungan Sosial adalah Informasi dari orang lain yang dicari dan dihargai oleh seseorang, yang dapat diberikan melalui beberapa cara, antara lain melalui perhatian, bantuan instrumental, pemberian informasi saat berada pada situasi yang menekan, serta informasi yang relevan dengan penilaian diri, dengan cara tersebut, setidaknya dukungan sosial dapat meringankan beban lansia apabila dihadapkan pada persoalan (Taylor, Peplau \& Sears, 2009). Secara teoritis dukungan sosial dapat menurunkan kecenderungan munculnya kejadian yang dapat mengakibatkan stres, hal tersebut karena interaksi dengan orang lain dapat memodifikasi atau mengubah persepsi individu pada kejadian sehingga dikatakan dapat mengurangi potensi munculnya stres (Lieberman dalam Azizah, 2011). Kajian mengenai dukungan sosial keluarga banyak ditemukan pada pasien penderita penyakit dan juga lansia. Dukungan sosial terdekat yang dapat diperoleh lansia adalah bersumber dari keluarga.

Dukungan sosial yang bersumber dari keluarga yang kemudian peneliti istilahkan sebagai dukungan sosial keluarga merupakan sikap, tindakan dan penerimaan keluarga terhadap penderita yang sakit. Anggota keluarga memandang bahwa orang yang mendukung selalu siap memberikan pertolongan dan bantuan jika diperlukan (Hanson dalam Achjar, 2010). Pada kenyataanya menurunnya kapasitas hubungan keakraban dengan keluarga dan berkurangnya interaksi dengan keluarga yang dicintai dapat menimbulkan perasaan tidak berguna, merasa disingkirkan, tidak dibutuhkan lagi sehingga mengakibatkan terjadinya depresi (Stoudemire dalam Azizah, 2011). Berdasarkan penjelasan tersebut, maka peneliti tertarik untuk meneliti tentang hubungan dukungan sosial keluarga dengan tingkat depresi pada lansia di Kelurahan Sading.

\section{METODE}

\section{Variabel dan definisi operasional}

Variabel independen pada penelitian ini adalah dukungan sosial keluarga dan tingkat depresi sebagai variabel dependen. Definisi operasional dari dukungan sosial keluarga adalah dukungan berupa dukungan instumental, dukungan informasional, dukungan emosional serta dukungan pada harga diri yang dirasakan oleh lansia dan diterima dari keluarga inti yaitu suami/istri, anak, menantu atau cucu. Definisi operasional dari tingkat depresi adalah gangguan emosional yang dirasakan oleh lansia berupa perasaan kurangnya minat terhadap aktivitas, sedih, sepi dan bosan, tidak berdaya, bersalah, berkurangnya perhatian dan konsentrasi, serta hilangnya semangat atau harapan terhadap masa depan, yang digolongkan ke dalam kriteria tidak depresi, depresi ringan, serta depresi sedang/berat.

\section{Karakteristik responden}

Populasi dalam penelitian ini adalah seluruh lansia yang berusia $\geq 60$ tahun yang berdomisili di Kelurahan Sading dengan jumlah 700 orang. Metode pengambilan sampel yang digunakan dalam penelitian ini probability sampling yaitu jenis simple random sampling yaitu metode pengambilan sampel yang dilakukan secara acak (Sugiyono, 2010). Jumlah responden pada penelitian ini sebanyak 233 lansia.

\section{Tempat Penelitian}

Penelitian dilakukan di Kelurahan Sading, Kecamatan Mengwi, Kabupaten Badung, Bali

\section{Alat Ukur}


Pada penelitian ini peneliti menggunakan kuesioner sebagai alat ukur untuk mengumpulkan data dan informasi dari subjek secara langsung. Kuisioner dalam penelitian ini meliputi skala dukungan sosial keluarga, skala tingkat depresi dan data demografi.

Skala dukungan sosial keluarga terdiri dari pernyataan favorable dan unfavorable yang terdiri dari 33 aitem. Skala ini menggunakan model Likert dengan 4 rentang sentimen yaitu Sangat Setuju, Setuju, Tidak Setuju dan Sangat Tidak Setuju. Hasil uji kesahihan item pada skala dukungan sosial keluarga yaitu memiliki koefisien korelasi yang bergerak dari 0,331 hingga 0,934. Skala dukungan sosial keluarga dalam penelitian ini memiliki nilai alpha $(\alpha)$ yaitu 0,968 , nilai ini menunjukkan bahwa skala mampu mencerminkan 96,8\% variasi yang terjadi pada skor murni sampel yang bersangkutan sehingga dapat digunakan untuk mengukur dukungan sosial keluarga.

Tingkat depresi diukur dengan menggunakan skala tingkat depresi yaitu geriatric depression scale versi indonesia (Yesavage dkk. Dalam Azizah, 2011). Skala tingkat depresi terdiri dari pernyataan favorable dan unfavorable yang terdiri dari 30 aitem. Aitem dalam skala ini berupa bentuk pertanyaan tertutup jenis yes/no question yaitu menyediakan dua jawaban alternatif berupa "ya" atau "tidak" pada setiap pertanyaan. Hasil uji kesahihan item pada skala tingkat depresi yaitu memiliki koefisien korelasi yang bergerak dari 0,316 hingga 0,836 . Skala tingkat depresi dalam penelitian ini memiliki nilai alpha $(\alpha)$ yaitu 0,944 , nilai ini menunjukkan bahwa skala mampu mencerminkan 94,4\% variasi yang terjadi pada skor murni sampel yang bersangkutan sehingga dapat digunakan untuk mengukur tingkat depresi.

Data tambahan yang digunakan dalam penelitian ini berupa data demografi. Data demografi berisi pertanyaan mengenai usia, jenis kelamin, tingkat pendidikan, sumber finansial, status pasangan, kegiatan yang diikuti subjek, pekerjaan serta penyakit yang diderita subjek. Data tambahan ini diharapkan dapat menjelaskan faktor-faktor lain yang mempengaruhi tingkat depresi lansia selain dukungan sosial keluarga.

\section{Metode pengumpulan data}

Metode pengumpulan data pada penelitian ini adalah dengan menggunakan kuisioner. Kuisioner dalam penelitian ini terdiri dari skala dukungan sosial keluarga, skala tingkat depresi dan data demografi. Skala dukungan sosial keluarga digunakan untuk mengetahui seberapa besar dukungan sosial keluarga yang dirasakan dan diterima oleh lansia. Skala tingkat depresi digunakan untuk mengetahui tingkat depresi yang dialami lansia. Data demografi digunakan sebagai data tambahan yang diharapkan dapat menjelaskan faktor-faktor lain yang mempengaruhi tingkat depresi pada lansia selain dukungan sosial keluarga.

\section{Analisa data}

Penelitian ini merupakan penelitian kuantitatif yang menggunakan uji korelasi. Uji korelasi bertujuan untuk melihat hubungan dan membuktikan hipotesis hubungan dua variabel (Sugiyono, 2011). Penentuan jenis statistik yang digunakan ditentukan terlebih dahulu sebelum kegiatan analisis data dilakukan. Menurut Sugiyono (2010), penggunaan statistik parametris maupun statistik nonparametris tergantung pada asumsi dan jenis data yang akan dianalisis. Adapun syarat asumsi dan jenis data dalam penggunaan statistik parametrik antara lain sampel data dipilih secara random, jenis data interval atau rasio serta data berdistribusi normal (Riduwan, 2012).

Data yang telah diperoleh, kemudian dilakukan uji normalitas. Apabila data terdistribusi normal, maka data dapat dianalisis dengan menggunakan statistik parametrik yaitu dengan teknik analisis korelasi Pearson Product Moment, namun apabila tidak terdistribusi normal, maka data dapat dianalisis dengan menggunakan statistik nonparametrik yaitu dengan teknik analisis korelasi Rank Spearman, karena sampel penelitian berukuran besar $(n>50)$ (Dahlan, 2011). Uji normalitas pada penelitian ini dilakukan dengan menggunakan Kolmogorov Smirnov.

Pada penelitian ini juga dilakukan analisis tambahan untuk mengetahui perbedaan variabel tingkat depresi pada data tambahan yaitu data demografi. Metode analisis data yang digunakan adalah statistik nonparametris yaitu U-Mann Whitney Test dan Kruskal Wallis Test. U-Mann Whitney bertujuan untuk mengetahui ada tidaknya perbedaan pada dua kelompok sampel yang independen (tidak berhubungan). Kruskal Wallis bertujuan untuk mengetahui ada tidaknya perbedaan pada tiga atau lebih kelompok sampel yang independen (tidak berhubungan) (Santoso, 2005).

\section{HASIL PENELITIAN}

\section{Data Demografi}

Data demografi menunjukkan bahwa karakteristik subjek yaitu sebagian besar subjek berusia 60-69 tahun, sebagian besar berjenis kelamin perempuan, sebagian besar tingkat pendidikannya adalah SR (setara SD). Dari data demografi juga diketahui bahwa sebagian besar sumber finansial berasal dari anak, sebagian besar subjek mengikuti kegiatan posyandu dan senam lansia, sebagian besar status pasangan subjek yaitu masih hidup, sebagian subjek masih memeiliki pekerjaan serta sebagian besar subjek tidak menderita penyakit. 


\section{Kategorisasi Dukungan Sosial Keluarga}

Kategorisasi pada dukungan sosial keluarga dilakukan dengan menggunakan rumus rentangan berdasarkan standar deviasi dan mean teoritis dilihat dari kurva normal (Azwar, 2012). Berdasarkan hasil kategorisasi terlihat bahwa persentase terbesar dukungan sosial keluarga pada kategori sangat tinggi yaitu sebanyak 59\%. Kategori rendah adalah persentase terkecil yaitu sebanyak $4,7 \%$ dan tidak terdapat subjek pada kategori skor sangat rendah. Kategori prestasi dijelaskan pada Tabel 1 Kategorisasi Subjek pada Skala Dukungan Sosial Keluarga berikut ini:

Tabel 1

Kategorisasi Subjek pada Skala Dukungan Sosial Keluarga

\begin{tabular}{cccc}
\hline Rentang Nilai & Kategori & Jumlah & Persentase \\
\hline$\leq 57,75$ & sangat rendah & 0 & $0 \%$ \\
\hline $57,75<\mathrm{X} \leq 74,25$ & Rendah & 11 & $4,7 \%$ \\
\hline $74,25<\mathrm{X} \leq 90,75$ & Sedang & 23 & $9,8 \%$ \\
\hline $90,75<\mathrm{X} \leq 107,25$ & Tinggi & 62 & $26,5 \%$ \\
\hline $107,25<$ & sangat tinggi & 137 & $59 \%$ \\
\hline
\end{tabular}

\section{Kategorisasi Tingkat Depresi}

Tingkat depresi dikategorikan kedalam 3 kategori berdasarkan banyaknya gejala depresi yang dirasakan oleh subjek (Azizah, 2011). Berdasarkan hasil kategorisasi terlihat bahwa persentase terbesar tingkat depresi pada kategori tidak depresi yaitu sebanyak $83,7 \%$. Kategori depresi ringan adalah persentase terkecil yaitu sebanyak $16,3 \%$ dan tidak terdapat subjek pada kategori depresi sedang/berat. Kategorisasi tingkat depresi dijelaskan pada Tabel 2. Kategorisasi Subjek pada Skala Tingkat Depresi berikut ini:

Tabel 2.

\begin{tabular}{cccc}
\multicolumn{4}{c}{ Kategorisasi Subjek pada Skala Tingkat Depresi } \\
\hline Rentang Nilai & Kategori & Jumlah & Persentase \\
\hline $0-10$ & Tidak depresi & 195 & $83,7 \%$ \\
\hline $11-20$ & Depresi ringan & 38 & $16,3 \%$ \\
\hline $21-30$ & Depresi sedang/berat & 0 & $0 \%$ \\
\hline
\end{tabular}

\section{Hasil Uji Normalitas}

Berdasarkan hasil uji normalitas diketahui bahwa sebaran data dukungan sosial keluarga memiliki nilai signifikansi dengan propabilitas (p) sebesar 0,000 dan sebaran data tingkat depresi memiliki nilai signifikansi dengan probabilitas ( $\mathrm{p}$ ) sebesar 0,000 . Nilai $\mathrm{p}=0,000$ menunjukkan bahwa data dukungan sosial keluarga dan tingkat depresi berdistribusi tidak normal $(\mathrm{p}<0,05)$. Berdasarkan hasil uji normalitas, diketahui bahwa data penelitian berdistribusi tidak normal, oleh karena itu penelitian ini menggunakan statistik nonparametrik berupa analisis korelasi Rank Spearman.

\section{Hasil Korelasi Rank Spearman}

Berdasarkan hasil uji Rank Spearman, terlihat bahwa nilai sig (2-tailed) yaitu 0,000, karena nilai sig (2-tailed) < 0,05 maka disimpulkan bahwa terdapat hubungan yang signifikan antara dukungan sosial keluarga dengan tingkat depresi. Koefisien korelasi $\mathrm{r}=-0,847$ menunjukkan bahwa korelasi antara dukungan sosial keluarga dan tingkat depresi adalah sebesar 0,847. Hubungan antara dukungan sosial keluarga dan tingkat depresi memiliki nilai negatif, hal tersebut menunjukkan bahwa hubungan yang terjadi yaitu berlawanan arah. Hubungan berlawanan arah yang dimaksud adalah apabila terjadi peningkatan dalam dukungan sosial keluarga, maka kecenderungan tingkat depresi akan mengalami penurunan. Apabila dukungan sosial keluarga mengalami penurunan, maka kecenderungan tingkat depresi akan mengalami peningkatan. Hasil analisis hubungan dukungan sosial keluarga dengan tingkat depresi pada lansia di Kelurahan Sading disajikan dalam Tabel 3. Hasil Uji Rank Spearman berikut ini:

\begin{tabular}{|c|c|c|c|}
\hline \multicolumn{4}{|c|}{ Hasil Uji Rank Spearman } \\
\hline & & $\begin{array}{l}\text { Dukungan Sosial } \\
\text { Keluarga }\end{array}$ & Tingkat Depresi \\
\hline \multirow[t]{3}{*}{$\begin{array}{l}\text { Dukungan Sosial } \\
\text { Keluarga }\end{array}$} & Correlation Coefficient & 1.000 & $-.847^{*}$ \\
\hline & Sig. (2-tailed) & & .000 \\
\hline & $\mathrm{N}$ & 233 & 233 \\
\hline \multirow{3}{*}{ Tingkat Depresi } & Correlation Coefficient & $-847^{*}$ & 1.000 \\
\hline & Sig. (2-tailed) & .000 & \\
\hline & $\mathrm{N}$ & 233 & 233 \\
\hline
\end{tabular}

\section{Hasil Analisis Tambahan}

Pada penelitian ini juga dilakukan analisis tambahan pada data demografi. Uji beda yang digunakan pada penelitian ini adalah U-Mann Whitney dan Kruskal Wallis Test. Hasil uji beda variabel tingkat depresi pada data tambahan dijelaskan pada Tabel 4. Hasil Uji Beda Tingkat Depresi pada Data Tambahan:

\begin{tabular}{lcc} 
& Tabel 4. \\
& Hasil Uji Beda Tingkat Depresi pada Data Tambahan \\
\multicolumn{1}{c}{ Data Tambahan } & $\begin{array}{c}\text { Nilai } \text { Asymp.Sig pada } \\
\text { Prestasi Akademik }\end{array}$ & Uji Beda \\
& 0,004 & U-Mann Whitney \\
\hline Usia subjek & 0,326 & U-Mann Whitney \\
\hline Jenis kelamin & 0,524 & Kruskal Wallis Test \\
\hline Tingkat pendidikan & 0,049 & Kruskal Wallis Test \\
\hline Sumber Finansial & 0,030 & U-Mann Whitney \\
\hline Status pasangan & 0,000 & U-Mann Whitney \\
\hline Penyakit & 0,300 & Kruskal Wallis Test \\
\hline Pekerjaan & 0,004 & U-Mann Whitney \\
\hline Kegiatan lansia yang diikuti subjek & &
\end{tabular}

Berdasarkan hasil uji beda tingkat depresi pada data tambahan terlihat bahwa nilai Asymp. Sig. yang terendah pada data tambahan sebesar 0,000 sedangkan yang tertinggi sebesar 0,524. Pada data jenis kelamin, tingkat pendidikan serta pekerjaan terlihat nilai asymp sig. lebih besar dari 0,05 $(p>0,05)$, hal ini berarti tidak terdapat perbedaan tingkat depresi pada jenis kelamin, tingkat pendidikan serta pekerjaan subjek. Pada data usia, sumber finansial, status pasangan, riwayat penyakit, serta kegiatan yang diikuti subjek nilai asymp sig. lebih kecil dari 0,05 $(\mathrm{p}<0,05)$. Hal tersebut berarti terdapat perbedaan tingkat depresi pada usia, sumber finansial, status pasangan, riwayat penyakit, serta kegiatan yang diikuti subjek. 


\section{PEMBAHASAN DAN KESIMPULAN}

\section{Korelasi antara Dukungan Sosial Keluarga dengan Tingkat Depresi}

Berdasarkan analisis yang telah dipaparkan di atas, maka dapat dikatakan bahwa H0 ditolak dan Ha diterima, sehingga "ada hubungan yang signifikan antara dukungan sosial keluarga dengan tingkat depresi pada lansia di Kelurahan Sading". Penerimaan hipotesis tersebut terbukti berdasarkan pada perhitungan statistik dengan menggunakan analisis korelasi Rank Spearman, yaitu koefisien korelasi (r) antara dukungan sosial keluarga dengan tingkat depresi sebesar $-0,847$. Koefisien korelasi yang bernilai negatif menunjukkan bahwa dukungan sosial keluarga memiliki hubungan berlawanan arah dengan tingkat depresi pada lansia di Kelurahan Sading. Hubungan berlawanan arah yang dimaksud adalah semakin meningkatnya dukungan sosial keluarga, maka kecenderungan tingkat depresi akan mengalami penurunan.

Hasil penelitian sesuai dengan hipotesis penelitian karena dukungan sosial keluarga merupakan faktor yang penting yang mempengaruhi terjadinya depresi (Maryam, dkk., 2008). Berdasarkan hasil kategorisasi tingkat depresi diketahui bahwa sebagian besar lansia di Kelurahan Sading berada pada kategori tidak depresi yaitu sebanyak $83,7 \%$, sisanya sebanyak $16,3 \%$ berada pada kategori depresi ringan. Sementara itu, hasil kategorisasi dukungan sosial keluarga menunjukkan bahwa sebagian besar lansia tergolong sangat tinggi yaitu sebesar 59\%. Pena, dkk., (2013), menyatakan lansia yang mendapatkan dukungan sosial, kemungkinan terjadinya depresi akan lebih rendah.

Lieberman (dalam Azizah, 2011) menyatakan bahwa dengan adanya dukungan sosial yang diperoleh dari orang terdekat yaitu keluarga dapat menurunkan kecenderungan munculnya kejadian yang mengakibatkan stres, adanya interaksi dengan keluarga dapat memodifikasi atau mengubah persepsi individu pada kejadian penuh stres, sehingga akan mengurangi potensi munculnya stres. Berdasarkan teori psikodinamik, stres merupakan prediktor yang baik dalam terjadinya depresi, banyak bukti yang menunjukkan bahwa stres akut dan kronis menyebabkan depresi. Salah satu kemungkinan bahwa dukungan sosial keluarga dapat meminimalkan keparahan depresi yaitu karena beban yang timbul akibat peristiwa-peristiwa penuh stres kurang dialami oleh lansia sebagai stres karena beban tersebut dapat dibicarakan dan diselesaikan bersama dengan keluarga (Semium, 2006).

\section{Usia Subjek}

Menurut Departemen Kesehatan RI (dalam Maryam dkk., 2008), lansia dimulai dari usia 60 tahun ke atas dan akan lebih beresiko mengalami gangguan kesehatan seperti depresi pada usia 70 tahun ke atas. Davison, Neale \& Kring (2010) menyatakan bahwa sering pertambahan usia, manusia hampir tanpa terhindarkan oleh sejumlah peristiwa dalam hidup yang dapat menyebabkan depresi. Hal tersebut terjadi karena semakin bertambahnya usia, maka individu secara alamiah akan menghadapi beberapa kondisi penurunan berupa kemampuan fisik, sosial, dan psikologis, kehilangan temanteman dan orang yang dicintai, serta kematian (Papalia, Sterns, Feldman \& Camp, 2007). Berdasarkan uji beda data usia, ditemukan perbedaan tingkat depresi pada lansia berdasarkan usia $(\mathrm{p}<0,05)$. Tingkat depresi pada lansia yang berusia 70 tahun ke atas lebih tinggi daripada lansia berusia 60-69 tahun.

\section{Sumber Finansial}

Sumber finansial yang berkurang setelah memasuki periode lansia merupakan faktor lainnya yang turut mempunyai peranan pada tingkat depresi lansia (Maryam dkk., 2008). Masalah ekonomi merupakan salah satu masalah yang umumnya dihadapi oleh lansia. terjadinya penurunan produktivitas kerja, memasuki masa pensiun atau berhentinya pekerjaan utama, hal tersebut berakibat pada menurunnya pendapatan yang terkait dengan pemenuhan kebutuhan seharihari. Padahal memasuki periode lansia, seseorang akan dihadapkan pada kebutuhan yang semakin meningkat. Bagi lansia yang tidak memiliki penghasilan yang mencukupi maka akan menghadapi masalah (Suardiman, 2011). Hal tersebut sesuai dengan hasil perhitungan statistik yang menunjukkan adanya perbedaan tingkat depresi yang signifikan pada lansia dengan sumber finansial yang berasal dari anak, suami atau diri sendiri $(\mathrm{p}<0,05)$. Tingkat depresi pada lansia dengan sumber finansial berasal dari diri sendiri lebih tinggi daripada dari anak dan suami.

\section{Status Pasangan}

Maryam dkk., (2008) menyatakan perpisahan dengan pasangan atau kematian merupakan faktor resiko terhadap tingginya depresi pada lansia. Menurut Suardiman (2011) lansia dengan status janda atau duda memiliki tingkat depresi lebih tinggi daripada lansia yang masih berpasangan. Menurut Papalia, Sterns, Feldman \& Camp (2007), individu yang mengalami peristiwa kematian istri atau suaminya, merasa tidak lagi memiliki peran pasangan hidup di dalam kehidupannya. Hal tersebut terjadi karena lansia yang telah terbiasa menjalani hidup bersama dan berbagi peran dengan pasangan hidupnya dalam waktu yang lama, oleh karena itu ketika pasangan hidupnya meninggal, maka sebagian diri mereka pun ikut hilang. Berdasarkan hasil perhitungan statistik yaitu terdapat perbedaan tingkat depresi yang signifikan pada lansia dengan status pasangan masih hidup ataupun telah meninggal $(p<0,05)$. Tingkat depresi pada lansia yang status pasangannya yangtelah meninggal lebih tinggi daripada lansia yang status pasangannya masih hidup. 


\section{Penyakit yang diderita subjek}

Periode lansia ditandai dengan terjadinya kemunduran sel-sel karena proses penuaan yang berakibat pada lemahnya organ, kemunduran fisik, dan timbul berbagai penyakit degeneratif (Suardiman, 2011). Suardiman (2011), penyakit yang diderita lansia tersebut tidak hanya berdampak pada terjadinya masalah kesehatan, namun juga sosial dan menjadi beban perekonomian bagi lansia karena penanganan penyakit memerlukan biaya. Terjadinya masalah kesehatan yaitu penyakit fisik merupakan hal yang paling dirasakan oleh lansia dan berpengaruh pada depresi yang dialami. Hal ini sejalan dengan perhitungan statistik, yang menemukan adanya perbedaan tingkat depresi yang signifikan pada lansia yang menderita penyakit dan lansia yang tidak menderita penyakit $(\mathrm{p}<0,05)$. Tingkat depresi pada lansia yang menderita penyakit lebih tinggi daripada lansia yang tidak menderita penyakit.

\section{Kegiatan yang diikuti subjek}

Azizah (2011) menyatakan dalam menjaga kesehatan baik fisik maupun kejiwaan, lansia justru harus tetap melakukan kegiatan yang berguna bagi kehidupannya, karena apabila tidak, maka akan mendatangkan penyakit bagi lansia. Suardiman (2011) menyatakan melalui kegiatan, lansia dapat berkumpul dan berkomunikasi dengan sesama lansia. Rasa kesepian dan tidak berguna seringkali muncul dari kurangnya aktivitas, apabila dibiarkan secara terus-menerus maka maka akan berdampak negatif bagi lansia. Di Kelurahan Sading terdapat 2 (dua) jenis kegiatan yang dilakukan secara rutin oleh lansia yaitu senam dan posyandu lansia. Data demografi menunjukkan bahwa sebesar $87,1 \%$ mengikuti kegiatan senam dan posyandu lansia, sementara sebesar 12,9\% tidak mengikuti kegiatan tersebut. Adanya kegiatan akan menimbulkan suatu rasa percaya diri dan meningkatkan harga diri (self-esteem) bagi lansia. Hal tersebut sangat penting bagi kehidupan lansia, karena hilangnya self-esteem dapat megakibatkan lansia merasa tidak berdaya, putus asa sehingga menyebabkan terjadinya depresi (Azizah, 2011). Dari perhitungan statistik, ada perbedaan tingkat depresi yang signifikan pada lansia yang mengikuti kegiatan dan tidak mengikuti kegiatan lansia $(\mathrm{p}<0,05)$. Tingkat depresi pada lansia yang tidak mengikuti kegiatan lansia lebih tinggi daripada lansia yang mengikuti kegiatan lansia.

\section{Kesimpulan}

Berdasarkan hasil analisis data yang telah dilakukan maka dapat disimpulkan bahwa ada hubungan yang signifikan antara dukungan sosial keluarga dengan tingkat depresi pada lansia di Kelurahan Sading. Hubungan yang terjadi yaitu hubungan berlawanan arah, yang memiliki arti bahwa semakin tinggi dukungan sosial keluarga maka tingkat depresi akan semakin rendah. Pada data demografi, ditemukan perbedaan yang signifikan antara usia, sumber biaya seharihari, status pasangan, riwayat penyakit, serta kegiatan yang diikuti lansia pada tingkat depresi.

\section{Saran}

Berdasarkan kesimpulan tersebut maka dapat disampaikan saran kepada lansia, keluarga dan peneliti selanjutnya. Saran bagi lansia yaitu menyadari bahwa tingkat depresi dipengaruhi oleh dukungan sosial keluarga, mencari dukungan sosial keluarga serta menjaga kesehatan.

Saran bagi keluarga yaitu mampu mengenali masalah yang dialami lansia, sehingga dapat membantu lansia dalam mengatasi masalah-masalah tersebut dengan memberikan dukungan sosial seperti dukungan informasional, instrumental, emosional dan dukungan pada harga diri. Keluarga juga diharapkan dapat menyadari dan mengenali gejala-gejala depresi lansia, agar dapat mencegah perkembangan gejala menjadi gangguan depresi. Bagi keluarga yang memiliki lansia dengan gangguan depresi, sebaiknya memeriksakan kondisi lansia ke tenaga medis agar dapat diberikan intervensi medis dengan pengobatan medis. Namun, penting diingat bahwa pengobatan medis memiliki efek samping bagi kesehatan organ lansia, oleh karena itu intervensi nonfarmakologis berupa terapi psikologis seperti terapi kognitif, interpersonal psychotherapy serta terapi keluarga, lebih dianjurkan dalam penyembuhan depresi lansia.

Saran bagi peneliti selanjutnya yaitu melakukan penelitian kualitatif mengenai dinamika kehidupan lanjut usia, masalah-masalah yang dialami oleh lansia serta dinamika dukungan informasional, dukungan instrumental, dukungan emosional dan dukungan pada harga diri dengan tingkat depresi lansia. Peneliti selanjutnya diharapkan meneliti dukungan sosial yang bersumber dari teman sebaya serta dari tenaga profesional untuk melihat variasi tingkat depresi serta meneliti hubungan antara kesehatan fisik, perpisahan dengan pasangan, perumahan dan transportasi dan sumber finansial dengan tingkat depresi sehingga dapat diketahui faktor yang mempengaruhi tingkat depresi pada lansia selain dukungan sosial keluarga.

\section{DAFTAR PUSTAKA}

Achjar, K. A. H. (2010). Asuhan Keperawatan Keluarga. Jakarta : Sagung Seto.

Anastasi, A. \& Urbina, S. (2006). Tes Psikologi. Jakarta : PT. Indeks. Andriani. (2013, Desember). Dampak Peningkatan Jumlah Lansia Terhadap Munculnya Fenomena Sosial Kodokushi Dying Alone Studi Pada Gempa Bumi Kobe 1995. Binus University. Diunduh dari http://japanese.binus.ac.id/2013/12/14/dampakpeningkatan-jumlah-lansia-terhadap-munculnya-fenomenasosial-

kodokushi\%E5\%AD\%A4\%E7\%8B\%AC\%E6\%AD\%BBdy ing-alone-studi-kasus-pada-gempa-bumi-kobe-1995/ tanggal 3 Oktober 2013. 
Astuti, V. W. (2010). Hubungan Dukungan Keluarga dengan Tingkat Depresi pada Lansia di Posyandu Sejahtera GBI Setia Bakti Kediri. Jurnal STIKES RS. Baptis Kediri, 3(2), 78-84.

Azizah, L. M. (2011). Keperawatan Lanjut Usia. Yogyakarta: Graha Ilmu.

Azwar, S. (2010). Reliabiltas dan Validitas. Yogyakarta : Pustaka Pelajar Offset.

Azwar, S. (2012). Penyusunan Skala Psikologi (ed. 2). Yogyakarta : Pustaka Pelajar.

Dahlan, M. S. (2011). Statistik untuk Kedokteran dan Kesehatan. Jakarta : Salemba Medika.

Data Rekapan Jumlah Penduduk Kelurahan Sading Tahun 2008. (2008). Kelurahan Sading, Kecamatan Mengwi, Kabupaten Badung.

Data Rekapan Jumlah Penduduk Kelurahan Sading Tahun 2009. (2009). Kelurahan Sading, Kecamatan Mengwi, Kabupaten Badung.

Data Rekapan Jumlah Penduduk Kelurahan Sading Tahun 2010. (2010). Kelurahan Sading, Kecamatan Mengwi, Kabupaten Badung.

Data Rekapan Jumlah Penduduk Kelurahan Sading Tahun 2013. (2013). Kelurahan Sading, Kecamatan Mengwi, Kabupaten Badung.

Davison, G. C., Neale, J. M., \& Kring, A. M. (2010). Psikologi Abnormal. Jakarta: Rajawali Pers.

Evy. (2008, Juni). Waspadai Depresi pada Lansia. Kompas. Diunduh dari

http://tekno.kompas.com/read/2008/06/26/1912429/waspad ai.depresi.pada.lansia. tanggal 20 Agustus 2013.

Ghozali, I. (2013). Aplikasi analisis multivariate dengan program IBM SPSS 21 update PLS regresi (ed.7). Semarang: Badan Penerbit Universitas Diponegoro.

Jumlah dan Distribusi Penduduk. (2010). Badan Pusat Statistik. Diunduh dari http://sp2010.bps.go.id/ tanggal 18 Nopember 2014.

Kim, J. I., Ae, M. C., Chae, Y. R. (2009). Prevalence and Predictors of Geriatric Depression in Cummunity-Dwelling Elderly. Asian Nursing Reseacrh, 3(3), 121-129.

Kristyaningsih, D. (2011). Hubungan Dukungan Keluarga dengan Tingkat Depresi pada Lansia. Jurnal Keperawatan, 1(1), 110.

Mahmud, J. (2005). Development Psychology. New Delhi : Efficient offset Printers.

Marchira, C. R., Wirasto, R. T., \& W, S. D. (2007). Pengaruh Faktorfaktor Psikososial dan Insomnia terhadap Depresi pada Lansia di Kota Yogyakarta. Berita Kedokteran Masyarakat, 23(1), 1-5.

Maryam, R. S., Ekasari, M. F., Rosidawati, Jubaedi, A. \& Batubara, I. (2008). Mengenal Usia Lanjutdan Perawatannya. Jakarta: SalembaMedika.

Nursalam. (2003). Konsep \& Penerapan Metodologi Penelitian Ilmu Keperawatan. Jakarta : SalembaMedika.

Olson, D. H., \& DeFrain, J. (2006). Marriages and Families: Intimacy, Diversity, and Strengths (ed. 5). New York: McGraw-Hill Inc.

Ouwehand, C., de Rider, D. T. D., \& Bensing, J. M. (2006). A Review of Successful Aging Models : Proposing Proactive
Coping as An ImportantAdditional Strategy. Clinical Psychology, 27, 873-884. doi : 10.1016/j.cpr.2006.11.003.

Papalia, D. E., Strerns, H. L., Feldman, R. D. \& Camp, C. J. (2007). Adult Development and Aging (ed. 3). New York : The McGraw-Hill Companies, Inc.

Pena, C. G., Wagner, F. A., Garcia, S. S, Bermudez, C. E., Cedillo, T. J., Zepeda, M. P., Aldana, R. R. \& Gallo, J. J. (2013). Late life Depressive Symptoms : Prediction Models of Change. Journal Of Affective Dissorder, 150, 886-894.

Puranomo. (2012, September). Jumlah Lansia di Jepang Bertambah. Diunduh dari http://www.beritajepang.com/jumlah-lansiadi-jepang-bertambah/ tanggal 3 Oktober 2013.

Purwanto. (2010). Metodologi Penelitian Kuantitatif :Untuk Psikologi dan Pendidikan. Yogyakarta : Pustaka Pelajar.

Riduwan. (2012). Belajar Mudah Penelitian untuk Guru, Karyawan, Peneliti Pemula. Bandung : Alfabeta.

Santoso, S. (2005). Mengatasi berbagai masalah statisti dengan SPSS versi 11.5. Jakarta: PT Elex Media Komputindo Kelompok Gramedia.

Santrock, J. W. (2009). Adolescence Perkembangan Remaja (ed. 3). Jakarta : Erlangga.

Saputri, M. A., \& Indrawati, E. S. (2011). Hubungan Dukungan Sosial dengan Depresi pada Lanjut Usia yang Tinggal di Panti Wreda Wening Wardoyo Jawa Tengah. Jurnal Psikologi Universitas Diponegoro, 9(1), 66-72.

Sarafino, E. P. (2007). Health Psychology Biopsychosocial Interactions (ed. 6). Canada : John Milley and Sons Inc.

Semium, Y. (2006). Kesehatan Mental 2. Yogyakarta : Kanisius.

Sensus Penduduk 2010. (2010). Badan Pusat Statistik. Diunduh dari http://sp2010.bps.go.id/ tanggal 21 Agustus 2013.

Stanley, M. \& Beare, P. G. (2007). Buku Ajar Keperawatan Gerontik. Jakarta : EGC.

Suardiman, S. P. (2011). Psikologi Usia Lanjut. Yogyakarta : Gajah Mada University Press.

Sugiyono. (2010). Metode Penelitian Kuantitatif Kualitatif dan R\&D. Bandung: Alfabeta.

Sukardi. (2005). Metodologi Penelitian Pendidikan Kompetensi dan Praktiknya. Jakarta: Bumi Aksara.

Taylor, S. E., Peplau, L. A., \& Sears, D. O. (2009). Psikologi Sosial (ed. 12). Jakarta: Kencana.

Undang-undang Republik Indonesia Nomor 19 Tahun 1998 tentang Kesejahteraan Lanjut Usia. (2014). Dewan Perwakilan Rakyat Repulik Indonesia. Diunduh dari http://www.dpr.go.id/uu/uu1998/UU_1998_13.pdf tanggal 12 April 2014.

Undang-undang Republik Indonesia Nomor 36 Tahun 2009 tentang Kesehatan. (2009). Kementrian Kesehatan Republik Indonesia. Diunduh dari http://www.depkes.go.id/downloads/UU_No._36_Th_2009 _ttg_Kesehatan.pdf tanggal 17 juni 2014.

Utari, A. (2012). Usia Harapan Hidup Tinggi Jumlah Lansia Makin Membengkak. Harian Terbit. Diunduh dari www.harianterbit.com/usia-harapan-hidup-tinggi-jumlahlansia-makin-membengkak tanggal 18 November 2013.

Penduduk Usia Lanjut. (2011). Kementrian Pemberdayaan Perempuan dan Perlindungan Anak Republik Indonesia. 
Diunduh dari http://www.menegpp.go.id/v2/index.php/datadaninformasi/ kependudukan?download=9\%3Apenduduk-lanjut-usia tanggal 1 oktober 2013.

Wulandari, A. Y. S. (2011). Kejadian dan Tingkat Depresi pada Lanjut Usia : Studi Perbandingan di Panti Wreda dan Komunitas. Naskah tidak dipublikasikan. Fakultas Kedokteran, Universitas Diponegoro. Semarang.

Yesavage, J.A., Brink, T.L., Rose, T.L., Lum, O., Huang, V., Adey, M.B., \& Leirer, V.O. (1983). Development and Validation of A Geriatric Depression Screening Scale: A Preliminary Report. Journal of Psychiatric Research, 17, 37-49. 